\title{
U-net Mimarileri ile Glioma Tümör Segmentasyonu Üzerine Bir Literatür Çalıșması
}

\author{
Ayşe Baştuğ Koç ${ }^{1,2^{*}}$, Devrim Akgün ${ }^{3}$ \\ ${ }^{1}$ Bursa Uludağ Üniversitesi, Gemlik Asım Kocabıyık Meslek Yüksek Okulu, Bilgisayar Programcıllı̆ı Bölümü, Bursa, Türkiye (ORCID: 0000-0002-8252-1728), \\ aysebastugkoc@uludag.edu.tr \\ 2 Sakarya Üniversitesi, Fen Bilimleri Enstitüsü, Bilgisayar ve Bilişim Mühendisliği Bölümü, Sakarya, Türkiye (ORCID: 0000-0002-8252-1728), \\ ${ }^{3}$ Sakarya Üniversitesi, Bilgisayar ve Bilişim Bilimleri Fakültesi, Yazılım Mühendisliği Bölümü, Sakarya, Türkiye (ORCID: 0000-0002-0770-599X), \\ dakgun@sakarya.edu.tr
}

(3rd International Congress on Human-Computer Interaction, Optimization and Robotic Applications June 11-13, 2021)

(DOI: $10.31590 /$ ejosat.959590)

ATIF/REFERENCE: Baştuğ Koç, A., Akgün, D. (2021). U-net Mimarileri ile Glioma Tümör Segmentasyonu Üzerine Bir Literatür Çalışması. Avrupa Bilim ve Teknoloji Dergisi, (26), 407-414.

$\ddot{\mathbf{O} z}$

Evrişimli sinir ağı yöntemlerinden biri olan U-net, sınırlı miktarda eğitim verisi kullanarak görüntüleri hassas bir şekilde bölümlere ayırabilen, tıbbi görüntü analizi için geliştirilmiş bir görüntü bölümleme tekniğidir. Basit, esnek ve genişletilebilir bir yapıda olup yüksek kalitede piksel düzeyinde bölütleme sonuçları sunmaktadır. Bu özellikleri sayesinde, tıbbi görüntüleme toplulukları içerisinde çok yüksek bir fayda sağlamakta ve tıbbi görüntüleme bölütleme görevleri için U-net ve varyasyonları yaygın bir şekilde kullanılmaktadır. Tomografi (CT) taramaları, Manyetik rezonans (MR) taramaları, X ışınları ve Mikroskopiye kadar büyük ana görüntü modalitelerinde U-net başarılı sonuçlar vermektedir. Ayrıca, U-net büyük ölçüde bölütleme görevlerinde kullanılsada, diğer uygulamalarda da U-net kullanımının örnekleri bulunmaktadır. U-net'in tıp ve diğer alanlarda kullanım potansiyeli her geçen gün artmaktadır. Mimari olarak U-net ve çeşitlerinin kullanıldığı tıbbi alandaki çalışmalar incelendiğinde en çok çalışılan alan beyin, en çok çalışılan görüntüleme yöntemi ise MR olarak karşımıza çıkmaktadır. MR tekniğinde, güçlü bir manyetik alan ortamında radyofrekans dalgaları aracılığıyla görüntü oluşturulmaktadır. Radyasyon içermeyen ve hastaya herhangi bir ilaç verilmeyen MR tekniği, yumuşak dokuların görüntülemesinde kullanılmaktadır. MR Görüntüleme, vücudun anatomisini ve fizyolojisini araştırmak, kas ve eklem hastalıkları ve anormalliği içeren patolojileri, tümörleri, iltihaplanma ve inme gibi nörolojik durumları, kalp ve kan damarlarındaki anormallikleri tespit etmek için radyolojide sıkça kullanılmaktadır. Yetişkinlerde beyinde en çok rastlanan, kansere sebep olan ve ölüm oranı fazla tümör çeşiti glial tümörlerdir. Glial tümörlerden biri olan gliomlar erişkinlerde primer beyin tümörlerinin \%75'ini oluşturur. Güvenilir bölütleme algoritmaları hekimlere doku ve yapıları nicel olarak inceleme imkânı vererek beyin ile ilgili hastalıkları teşhis ve analiz etmede yardımcı olabilmektedir. Ancak beyin dokularının iç içe ve karışık şekli, türdeş olmayan yoğunluk dağılımı, belirsiz sınırları, gürültülü yapısı ve komşu beyin dokuları arasındaki düşük zıtlık sebebiyle beyin dokularının bölütlenmesi çok zorlayıcı bir görevdir. Söz konusu glial tümörler olduğunda aktif ve nekrotik (ölü) bölümler barındıran tümörün çok türlü yapısından dolayı bölütleme işlemi daha da karmaşıklaşmaktadır. Tüm glial tümörlerde ölü ve aktif bölümler arasında belirgin bir sınır olmamakta ve tümörlerin bazılarında nekrotik bölümler varolmaktayken bir kısmında bulunmaması da bölütlemeyi güçleştirmektedir. Literatürde U-net mimarileri, bahsedilen zorlukların üstesinden gelerek başarılı bir şekilde beyin glioma tümörlerinin segmentasyonununda kullanılmıştır. $\mathrm{Bu}$ incelemede son yıllarda U-net mimarileri kullanılarak beyin MR görüntüleri üzerinde BRATS veri setleri glioma tümör segmentasyonu yapan çeşitli çalışmalar derlenmiş ve bunlar hakkında karşılaştırmalı bilgiler sunulmuştur.

Anahtar Kelimeler: U-net, Glioma Tümör, Bölütleme.

\section{A Literature Study on Glioma Tumor Segmentation with U-net Architectures}

\begin{abstract}
U-net, one of the convolutional neural network methods, is an image segmentation technique developed for medical image analysis that can precisely segment images using a limited amount of training data. It has a simple, flexible and expandable structure and offers high quality pixel-level segmentation results. Thanks to these features, it provides a very high benefit in medical imaging communities, and the U-net and its variations are widely used for medical imaging segmentation tasks. U-net gives successful results in major main image modalities such as Tomography (CT) scans, Magnetic resonance (MR) scans, X-rays and Microscopy. Also,
\end{abstract}

* Sorumlu Yazar: aysebastugkoc@uludag.edu.tr 
although the U-net is largely used in segmentation tasks, there are examples of using U-net in other applications as well. The potential of U-net's use in medicine and other fields is increasing day by day. When examining the studies in the medical field where U-net and its varieties are used architecturally, the most studied area is the brain, and the most studied imaging method is MR. In the MRI technique, images are created by radiofrequency waves in a strong magnetic field environment. The MR technique, which does not contain radiation and does not give any medication to the patient, is used in the imaging of soft tissues. MRI is widely used in radiology to investigate the anatomy and physiology of the body, to detect pathologies including muscle and joint diseases and abnormalities, tumors, neurological conditions such as inflammation and stroke, and abnormalities in the heart and blood vessels. Glial tumors are the most common type of tumors in the brain that cause cancer and have a high mortality rate. Gliomas, one of the glial tumors, constitute $75 \%$ of primary brain tumors in adults. Reliable segmentation algorithms can help physicians to diagnose and analyze brain-related diseases by allowing them to quantitatively examine tissues and structures. However, the segmentation of the brain tissues is a very challenging task due to the intertwined and mixed shape of the brain tissues, the heterogeneous density distribution, the vague boundaries, the noisy nature, and the low contrast between neighboring brain tissues. When it comes to glial tumors, the segmentation process becomes more complicated due to the multifarious nature of the tumor, which contains active and necrotic (dead) parts. In all glial tumors, there is no distinct boundary between dead and active parts, and some tumors have necrotic parts, while some of them do not exist, making segmentation difficult. In the literature, U-net architectures have been successfully used in the segmentation of brain glioma tumors, overcoming the mentioned difficulties. In this review, various studies using U-net architectures on BRATS datasets for glioma tumor segmentation on brain MRI images were compiled in recent years and comparative information about them was presented.

\section{Keywords: U-net, Glioma Tumor, Segmentation.}

\section{Giriş}

Son yıllarda bilgisayarlı görme alanında derin öğrenmedeki gelişmeler sayesinde, tıbbi görüntülerin analizinde derin ögrenme giderek daha fazla kullanılmaktadır. Derin öğrenmenin kullanımı birçok farklı alanda hızlı bir büyüme gösterirken, tıbbi görüntüleme alanında hala bazı zorluklarla karşı karşıya kalmaktadır. Yıllarca bu çeşitli zorlukların üstesinden gelmek için birçok çığır açan yöntem geliştirilmiştir. Şimdiye kadarki en başarılı görüntü analizi yöntemleri derin öğrenme yöntemlerinden olan evrişimli sinir ağlarıdır $(\mathrm{CNN})$. Görüntü analizi için kullanılan AlexNet, ResNet, VGG ve U-Net gibi birkaç popüler $\mathrm{CNN}$ mimarisi vardır. $\mathrm{Bu} \mathrm{CNN}$ yöntemlerinden, U-net olağanüstü başarılar elde etmiştir ve bu nedenle tıbbi görüntü segmentasyonları için popüler teknoloji haline gelmiştir (Siddique, Sidike, Elkin ve Devabhaktuni, 2020).

CNN yöntemlerinden biri olan U-net (Ronneberger, Fischer ve Brox, 2015), sınırlı miktarda eğitim verisi kullanarak görüntüleri hassas bir şekilde bölümlere ayırabilen, tıbbi görüntü analizi için geliştirilmiş bir görüntü bölümleme tekniğidir. Basit, esnek ve genişletilebilir bir yapıda olup yüksek kalitede piksel düzeyinde bölütleme sonuçları sunmaktadır. Bu özelliklerinden dolayı, tıbbi görüntüleme toplulukları içerisinde yüksek bir başarı sağlamakta ve tıbbi görüntüleme bölütleme görevleri için U-net ve varyasyonları yaygın bir şekilde kullanılmaktadır. CT taramaları, MR taramaları, X ışınları ve Mikroskopiye kadar birçok görüntü türlerinde U-net faydalı sonuçlar vermektedir. Büyük ölçüde U-net bölütleme görevlerinde kullanılsada, diğer uygulamalarda (sınıflandırma gibi) da U-net kullanımının örnekleri mevcuttur. U-net'in tıp ve diğer alanlarda her geçen gün kullanım potansiyeli artmaktadır. Mimari olarak U-net ve çeşitlerinin kullanıldığı sağlık alandaki çalışmalar incelendiğinde en çok çalışılan alan beyin, en çok çalışılan görüntüleme yöntemi ise MR olarak karşımıza çıkmaktadır. $\mathrm{Bu}$ inceleme kapsamında U-net mimarileri kullanılarak beyin MR görüntüleri üzerinde beyinde en sık görülen ve ölüm oranının yüksek olduğu glioma tümör segmentasyonu yapan çalışmalar incelenecektir.

Beyin tümörleri, beyin dokusunda veya etrafındaki patolojik hücrelerin anormal ve kontrolsüz çoğalması ile oluşmaktadır. Kökenlerine göre kabaca birincil ve ikincil beyin tümörleri olarak iki kategoriye ayrılabilirler. Birincil beyin tümörlerinde, hücrelerin anormal büyümesi beynin içinde başlar; ikincil beyin tümörleri (metastatik tümörler) kanserli hücrelerin, göğüs, akciğer, böbrekler gibi vücudun diğer bölümlerinden beyne yayılmasıyla oluşur. Birincil beyin tümörü kanserli (kötü huylu) veya kanserli olmayan (iyi huylu) olabilir. En yaygın birincil beyin tümörü tipi, gliomlardır. Beyin glial hücrelerinden ortaya çıkar. Yetişkinlerde beyinde en çok rastlanan, kansere sebep olan ve ölüm oranı fazla tümör çeşiti glial tümörlerdir. Gliomlar erişkinlerde birincil beyin tümörlerinin \%75'ini oluşturur (Tüzün, Hanağası, Sabanc1, Demir ve Yazıc1, y.y.). Düşük dereceli (yavaş büyüyen) glioma (LGG) veya yüksek dereceli (hızlı büyüyen) glioma (HGG) olarak 2 türü vardır. Aynı zamanda glioblastoma multiform (GBM) olarak da adlandırılır (Louis ve diğerleri, 2016). Gliomlar, bulundukları yere ve büyüme oranlarına bağlı olarak beyin işlev bozukluğuna neden olabilir ve yaşamı tehdit edebilir, bu nedenle erken teşhisleri başarılı tedavi ihtimalini büyük ölçüde artırır. Gliomalı hastaların derin özelliklerinin MR görüntüleme ile çıkarılması genel hayatta kalma süresinin tahmini için önemlidir (Nadeem ve diğerleri, 2020). MR görüntüleme, beynin ayrıntılı görüntülerini sağlayabilen noninvazif radyasyonsuz bir tanı aracıdır ve yumuşak doku kontrastını gösterme yeteneği nedeniyle standart bir teknik olarak kabul edilir. MR görüntüleme, vücudun anatomisini ve fizyolojisini araştırmak, kas ve eklem hastalıkları ve anormalliği içeren patolojileri, tümörleri, iltihaplanma ve inme gibi nörolojik durumları, kalp ve kan damarlarındaki anormallikleri tespit etmek için radyolojide sıkça kullanılmaktadır (Chihati ve Gaceb, 2020).

Beyin tümörlerinin çoğu için ameliyat olağan tedavi olsada, fiziksel olarak çıkarılamayan tümörlerin büyümesini ve yayılmasını yavaşlatmak veya durdurmak için radyasyon ve kemoterapi kullanılabilir. Fakat sağlıklı dokuları korumak için herhangi bir ameliyat veya tedavi planlamadan önce, tümörü segmentlere ayırmak çok önemlidir. Beyin tümörü segmentasyonu; aktif tümör, ödem ve nekroz gibi farklı tümör dokularının, gri madde, beyaz madde ve beyin omurilik sıvısı gibi normal beyin dokularından teşhis edilmesini, tanımlanmasını ve ayrılmasını içerir. Beyin glioma tümörünün yapısı Şekil 1'de MR görüntüsü üzerinde gösterilmiştir. Her bir MR sekansı belirli bir dokuyu belirgin göstermek için dikkatlice tasarlanmıştır. Her bir sekansın faydasını ve sınırlarını anlamak önemlidir, böylece uygun MR sekansları seçilir ve hastanın durumuna göre tarama yapılır. Beyin bölütleme işlemi gerçekleştirmeden önce hangi dokunun hangi MR görüntü sekansında net bir şekilde görüldüğü saptanmalıdır. Tümör 
alanlarını tespiti için daha çok T1 ve T2 MR sekans görüntüleri incelenerek tümör hangisinde daha net görülüyorsa kullanılır. Ödemli alanlarının tespiti için de genellikle T2 veya FLAIR MR sekans görüntüleri kullanılır (Mathews ve Mohamed, 2020).
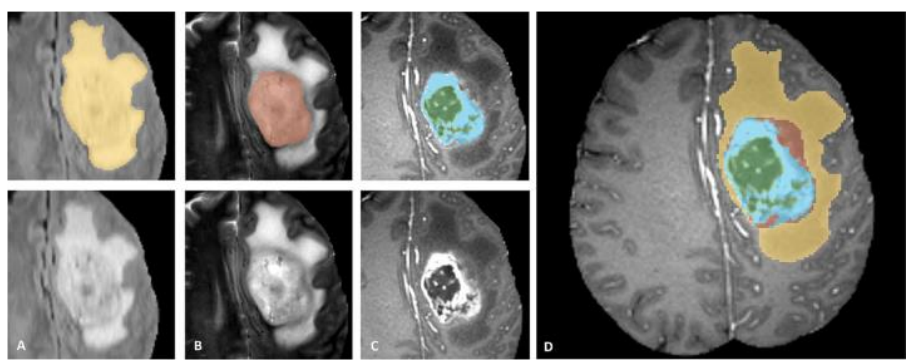

Şekil 1. Üç MR Görüntüleme Yöntemi ile Tümör Görünümü $(A=$

FLAIR, $B=T 2, C=T 1 c)$ ve Bunların Birleşimi(D). Soldan

Sağa: Tüm Tümör (Whole Tumor (WT)) (Sart), Tümör Çekirdeği

(Tumor Core(TC)) (Kırmızı), Aktif Tümör Yapılarl (Enhancing

Tumor (ET)) (Açık Mavi), Kistik / Nekrotik (Ölü Doku)

Yapı(Yeşil) (Menze ve diğerleri, 2014).

Segmentasyon klinik rutinde, teşhis, tümör ilerlemesinin izlenmesi, tedavi planlaması, hastalık sonucunun tahmini için değerli bilgiler sağlar. Bununla birlikte, radyolojik görüntülerde doğru tümör segmentasyonu hala zorlu bir görevdir. Çünkü bu tümörler heterojen bir görünüme sahiptir ve beynin herhangi bir yerinde, herhangi bir boyut ve şekilde ortaya çıkabilir ve sınırları genellikle düzensiz, bulanık olup sağlıklı dokulardan ayırt edilmesi oldukça zordur (Havaei ve diğerleri, 2017). Ayrıca MR görüntülerinde voksel değerlerinin ölçeği standardize edilmediğinden patolojik dokuların görünümü kurumdan kuruma değişiklik gösterebilir. MR görüntülerinde tümör alt bölgelerini manuel olarak dilimlere ayırmak uzmanlar gerektirir. Manuel segmentasyon, uzmanlar arası değişkenliğe eğilimli olan pahalı, zaman alıcı ve sıkıcı bir görevdir. Beyin tümörünün erken teşhisi için tam otomatik ve bilgisayar destekli segmentasyon algoritmalarının kullanılması hekimlere yardımcı olmakta ve onların işlerini kolaylaştırmaktadır. Birçok araştırmacının önerdiği çeşitli segmentasyon yöntemleri bulunmaktadır. Özellikle son zamanlarda derin öğrenme yöntemlerinin gelişmesiyle tıbbi görüntü segmentasyonu alanında dikkate değer başarılar gerçekleştirilmiştir. Derin öğrenme yöntemlerinden, evrişimli bir sinir ağı olan U-net olağanüstü başarılar elde etmiştir ve bu nedenle tıbbi görüntü segmentasyonları için popüler ve yaygın bir teknoloji olmuştur.

\section{Materyal ve Metot}

\subsection{U-net}

U-net (Ronneberger ve diğerleri, 2015), öncelikle görüntü bölümleme için tasarlanmış bir evrişimli sinir ağı mimarisidir ve yapısı Şekil 2'de gösterilmektedir. U-net'in eğitim süresi nispeten kısadır, basit bir yapıya ve daha az parametreye sahiptir. Diğer ağlara kıyasla daha az uygulama verisi talep etmektedir. U-net simetriktir, alt örnekleme yolu ile üst örnekleme yolu arasındaki atlama bağlantıları bulunmaktadır. $\mathrm{Bu}$ simetrik yollarından dolayı $\mathrm{U}$ şekline benzediği için bu ismi almıştır. Bir daralan alt örnekleme yolundan (sol taraf) ve genişleyen üst örnekleme yolundan (sağ taraf) oluşmaktadır. Alt örnekleme yolu, tipik bir konvolüsyonel ağdır. 4 bloktan oluşur ve her blok 2 adet $3 \times 3$ konvolüsyon katman $1+$ aktivasyon fonksiyonu (toplu normalleștirme ile) ve bir adet $2 \times 2$ maksimum havuzlama katmanı içerir. Özellik haritalarının sayısı her havuzlama işleminde ikiye katlanır. Alt örnekleme yolunun amacı, segmentasyon yapabilmek için girdi görüntüsünün içeriğini yakalamaktır. Bu bağlamsal bilgi daha sonra atlama bağlantıları yoluyla örnekleme yoluna aktarılır. Genişleyen üst örnekleme yolu da 4 bloktan oluşmaktadır. Bu bloklar dekonvolüsyon katmanı, alt örnekleme yolundan gelen özellik haritası ile birleştirme, $3 \times 3$ konvolüsyon tabakası + aktivasyon fonksiyonu (toplu normalleştirme ile) adımlarını içerir. Son olarak, özellik haritasını gerekli sayıda kanala indirgemek ve segmentli görüntüyü üretmek için ek bir $1 \times 1$ konvolüsyon işlemi uygulanır.

U-net yapısının sahip olduğu bazı üstünlükler vardır. Bunlar: 1.Ağı eğitmek için sınırlı sayıda örneği destekler. 2.Çok ölçekli bir tanıma ve füzyon ile görüntü özelliklerinin farkına varır. 3.Basit ve esnek bir yapısı vardır. 4.Yüksek kalitede piksel düzeyinde bölütleme sonuçları sunar. Orijinal U-net yalnızca tıbbi segmentasyon uygulamalarında iyi bir performans göstermekle kalmaz, aynı zamanda esnek ve genişletilebilir yapıya sahiptir. Böylece geliştirilmiş model, farklı görüntülerde yeni görevlere başarılı bir şekilde uyum sağlayabilir(L. Liu ve diğerleri, 2020). U-net, 2015'teki ortaya çıkışından bu yana, tıbbi görüntüleme kullanımında bir patlama görmüştür. Bu durumda, U-net mimarisinde araştırmacılar tarafından yeni yöntemler uygulayan veya diğer görüntüleme yöntemlerini U-net'e dahil eden birçok gelişme olmuştur. Sadece tıbbi alanda değil farklı birçok alanlarda da kullanımı her geçen gün artmaktadır.

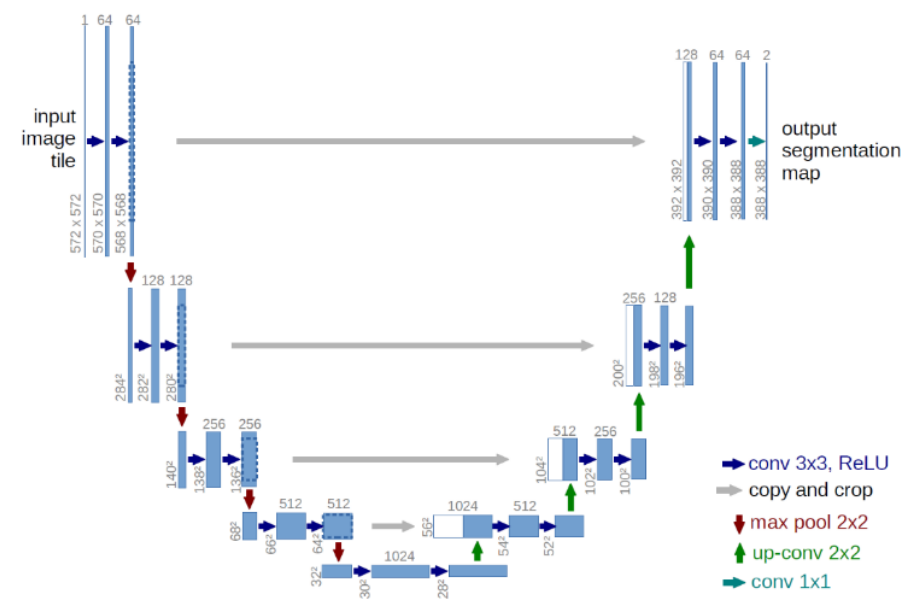

Şekil 2.U-net Yapısı (Ronneberger ve diğerleri, 2015). Renkli Oklar Farklı İşlemleri (Să̆ Alt Alanda Belirtilen), Mavi Kutular Her Katmandaki Özellik Haritasını ve Beyaz Kutular, Alt Örnekleme Yolundan Kırpılan Özellik Haritalarını Temsil Eder.

\subsection{Değerlendirme Ölçütleri}

Segmentasyon performans değerlendirmesi birkaç yolla yapılabilmektedir. Araştırmacılar sonuçları doğrulamak için farklı teknikler kullanmışlardır. Bölütleme çalışmalarında daha çok pozitif tabanlı metrikler kullanılmaktadır. Çünkü bölütlemede örtüşme alanlarının (Doğru pozitiflerin sayısı, Yanlış pozitiflerin sayısı, Yanlış negatiflerin sayısı) nitelendiği ölçütler önemlidir. Beyin glioma tümörü segmentasyonu için en yaygın performans değerlendirme ölçütleri; Dice Örtüşme İndeksi veya Dice Benzerlik Katsayısı, Özgüllük(Specificity), Hassasiyet(Sensitivity)'dir (Rajput ve Raval, 2020).

Dice skoru, etiketlenmiş ve tahmin edilmiş bölgeler arasındaki çakışmayı göstermektedir. Etkin örtüşme alanının bütün bir birleşimde ne kadar etkin olduğunu ifade eder. Dice skoru, kesin referans ile tahmin arasındaki örtüşme tabanlı bir 
ölçüt olup 0-1 arasında değer alır. Örtüşme alanı, birleşme alanına eşit ise 1'e eşittir ve mükemmel bir bölütlemenin gerçekleştiği söylenebilir. Denklem 1'deki gibi hesaplanır. Her tümör bölgesi için $\mathrm{P}$ model tahminini ve $\mathrm{T}$ temel gerçek etiketlerini temsil etmektedir.

$$
\operatorname{Dice} \operatorname{skoru}(P, T)=\frac{2 *|P \cap T|}{|P|+|T|}
$$

Özgüllük, doğru şekilde tanımlanan negatif örneklerin oranını ölçer. Denklem 2'deki gibi hesaplanır. Burada TN doğru negatiflerin sayısını, FP yanlış pozitiflerin sayısını verir.

$$
\text { Özgüllü } k=\frac{T N}{T N+F P}
$$

Hassasiyet, pozitif örneklerin başarılı tahminin oranını ölçer. Denklem 3'deki gibi hesaplanır. Burada TP doğru pozitiflerin sayısını, FN yanlış negatiflerin sayısını verir.

$$
\text { Hassasiyet }=\frac{T P}{T P+F N}
$$

\section{Literatür Çalışması}

\subsection{U-net ile Beyin Tümörü Segmentasyonu}

Beyin tümörü segmentasyonu yöntemleri yaygın olarak BRATS (Menze ve diğerleri, 2014), (Bakas ve diğerleri, 2017), (Bakas ve diğerleri, 2018) veri kümelerini kullanmaktadır. Yöntemler bu veri seti ile iyi bir şekilde karşılaştırılabilinmektedir. BRATS meydan okuması, MR görüntü taramalarında beyin tümörlerinin segmentasyonu için en yeni yöntemleri değerlendirmek için MICCAI konferansı ile birlikte y1llık olarak düzenlenmektedir. $\mathrm{Bu}$ meydan okuma, yöntemlerin performanslarını tarafsız bir şekilde değerlendirmek ve karşılaştırmak için açıklamalı yüksek dereceli gliomalar ve düşük dereceli gliomalardan oluşan geniş bir veri seti kümesi sağlamaktadır. Tüm BRATS MR görüntülerinin kafatası soyulmuş, aynı anatomik şablon üzerinde ortak kaydedilmiş, aynı çözünürlükte enterpolasyonlu ve birkaç değerlendirici tarafından manuel olarak bölümlere ayrılmıştır. $\mathrm{Bu}$ ek açıklamaları radyologlar tarafından onaylanmıştır. BRATS veri seti, 2012'de ilk olarak oluşturulmasından bu yana sürekli olarak güncellenmektedir. BRATS veri seti, 4 sekanslı beyin MR görüntü modaliteleri içermektedir: T1 MR, T2 MR, gadolinyum kontrastlı T1 ağırlıklı (T1-Gd) MR ve Sıvı Zayıflatılmış Ters Çevirme (FLAIR) MR. Her sekans tanıda farklı bir rol oynamaktadır. Genel olarak T1 MR görüntülerinde sağlıklı dokular ayırt edilebilir, T2 MR görüntülerde ödemli bölgeler gösterilir, tümör sınırını ayırt etmek için T1-Gd MR görüntüler kullanılır, FLAIR MR görüntülerinde ödemli bölgeler beyin omurilik sıvısından ayırt edilebilir (Chihati ve Gaceb, 2020).
U-net tabanlı modellerin diğer beyin tümörü segmentasyonu modellerine göre daha üstün olduğu kanıtlanmıştır. Basit ve yüksek doğrulukta olması sebebiyle BRATS 2018 yarışmasına yapılan \% 50'den fazla başvuru U-net'e dayalı olmuştur (Ghaffari, Sowmya ve Oliver, 2019). Beyin Glioma tümörü segmentasyonu için U-net derin öğrenme mimarisini ve varyasyonlarını ve 2015-2020 yılları arasındaki BRATS veri setlerini kullanan bazı son yıllardaki çalışmalara Tablo 1'de genel bir bakış yapılmıştır. $\mathrm{Bu}$ çalışmaların performans değerlendirmeleri Dice skorları ile sunulmuştur. Araştırmacılar U-net modelini değiştirme, veri kümesi boyutunu artırma, ön işleme, parametre optimizasyonları gibi farklı teknik çalışmalarla Dice skor değerini yükseltmeye çalışmışlardır. Veri artırma, örneklerin boyutunu artırmaya ve orijinal veriye rastgele varyasyonlar ekleyerek aşırı uyumu azaltmaya yardımcı olmuştur.

(Kim, 2017) çalışmasında, artan derinliğin performansı iyileştirip iyileştirmediğini test etmek için U-net'e çift evrişim katmanları, başlangıç modülleri ve yoğun modüller gibi bir dizi değişiklik ekleyerek derin 2 boyutlu bir mimari elde etmişlerdir. Sonuçlar, derin mimarilerin performansı artırdığını göstermiştir. Ayrıca, veri artırma yapmadan görüntüler üzerinde yapılan farklı oryantasyonlar ile eğitim yaparak performansı artırmışlardır. (Hu ve Xia, 2017) çalışmalarında, çok sekanslı MR görüntüleme kullanarak nekroz, ödem, artışta olan ve artış göstermeyen tümör dahil olmak üzere müşterek beyin tümörü tespiti ve tümör içi yapı segmentasyonu için 3 boyutlu derin sinir ağı tabanlı bir algoritma önermişlerdir. Kademeli U-net'den oluşan bir topluluk, tümörü saptamak ve tümör içi yapı segmentasyonu için derin bir evrişimli sinir ağı oluşturmuşladır. Sonuçlar umut verici bir performansa sahip olmuştur. (Shreyas ve Pankajakshan, 2017) çalışmalarında, rekabetçi performans ve son teknoloji modelden daha hızlı çalışma süresi ile sonuçlanan yeni ancak basit bir tamamen evrişimli ağ (FCN) önermişlerdir. Yöntemleri o günün son teknolojisindenden yaklaşık 18 kat daha hızlıdır. (Isensee ve diğerleri, 2018) çalışmalarında, BRATS 2018 veri seti üzerinde iyi eğitilmiş bir U-net'in etkinliğini göstermişlerdir. Araştırmacıların çoğunun segmentasyon performansını iyileştirmeyi amaçlayan mimari modifikasyonlarla birbirlerini en iyi şekilde kullandığı göz önüne alındığında bu çalışma özellikle ilginçtir. Segmentasyon performansını iyileştirmek yerine, yalnızca küçük değişiklere sahip olan iyi eğitilmiş bir U-net'in yenilmesinin zor olduğunu savunarak eğitim sürecine odaklanmışlardır. $\mathrm{Bu}$ yapı, meydan okumaya 60 'tan fazla takımın katıldığı BRATS 2018'de ikinci sırada yer almıştır. (Kong ve diğerleri, 2018) çalışmalarında, U-net modelini genişletmişlerdir ve farklı bölge tabanlı bağlamı birleştiren küresel bağlam bilgisini araştıran yeni bir hibrit piramit U-net (HPU-Net) modeli önermişlerdir. Global bağlam bilgisi kombinasyonu, tümör segmentasyon görevlerinde kaliteli sonuçlar üretmek için etkilidir ve HPU-Net'in, piksel düzeyinde tahmin için daha iyi bir çerçeve sağladığını belirtmişlerdir. 
Tablo 1.Beyin Tümörü Segmentasyonu İçin U-net Derin Öğrenme Mimarisini Kullanan Çalışmalar

\begin{tabular}{|c|c|c|c|c|c|}
\hline \multirow{2}{*}{ Referans } & \multirow{2}{*}{ Metot } & \multirow{2}{*}{ Veriseti Adı } & \multicolumn{3}{|c|}{ Değerlendirme (Dice Skoru) } \\
\hline & & & WT & CT & ET \\
\hline (Kim, 2017) & $\begin{array}{c}\text { Çift konvolüsyon katmanı, Başlangıç modülü ve } \\
\text { Yoğunluk modülü eklenen bir U-net }\end{array}$ & BRATS 2017 & 0.88 & 0.73 & 0.75 \\
\hline (Hu ve Xia, 2017) & 3 boyutlu derin sinir ağ, Basamaklı U-net & BRATS 2017 & 0.81 & 0.69 & 0.55 \\
\hline $\begin{array}{c}\text { (Shreyas ve } \\
\text { Pankajakshan, 2017) }\end{array}$ & U-net & BRATS 2015 & 0.83 & 0.75 & 0.72 \\
\hline $\begin{array}{l}\text { (Isensee ve diğerleri, } \\
\text { 2018) }\end{array}$ & 3 boyutlu U-net & BRATS 2018 & 0.87 & 0.80 & 0.77 \\
\hline $\begin{array}{l}\text { (Kong ve diğerleri, } \\
\text { 2018) }\end{array}$ & Yeni Hibrit piramit U-net (HPU-net) & BRATS 2015 & 0.90 & 0.71 & 0.78 \\
\hline $\begin{array}{l}\text { (W. Chen ve diğerleri, } \\
\text { 2018) }\end{array}$ & $\begin{array}{l}\text { Başlangıç bloğu ve Artık bloğu olan Ayrılabilir } \\
3 \text { boyutlu U-net (S3D-UNet) }\end{array}$ & BRATS 2018 & 0.89 & 0.83 & 0.74 \\
\hline \multirow{4}{*}{$\begin{array}{l}\text { (S. Chen, Ding ve Liu, } \\
\text { 2019) }\end{array}$} & \multirow{4}{*}{ Çift kuvvet eğitimi ile U-net } & \multirow{4}{*}{$\begin{array}{l}\text { BRATS } 2015 \\
\text { BRATS } 2017\end{array}$} & \multicolumn{3}{|c|}{ BRATS 2015} \\
\hline & & & 0.84 & 0.69 & 0.64 \\
\hline & & & \multicolumn{3}{|c|}{ BRATS 2017} \\
\hline & & & 0.89 & 0.78 & 0.70 \\
\hline $\begin{array}{l}\text { (H. Liu ve diğerleri, } \\
\text { 2019) }\end{array}$ & Basamaklı U-net (CU-Net) & BRATS 2017 & 0.88 & 0.83 & 0.76 \\
\hline $\begin{array}{l}\text { (Wang ve diğerleri, } \\
\text { 2019) }\end{array}$ & $\begin{array}{c}\text { Beyin bazlı normalizasyon ve yama stratejileri } \\
\text { yardımıyla } 3 \text { boyutlu U-net }\end{array}$ & BRATS 2019 & 0.894 & 0.807 & 0.737 \\
\hline $\begin{array}{l}\text { (Henry ve diğerleri, } \\
\text { 2020) }\end{array}$ & $\begin{array}{c}\text { Derinlemesine denetim ve stokastik ağırlık ortalamasına } \\
\text { sahip } 3 \text { boyutlu U-net }\end{array}$ & BRATS 2020 & 0.91 & 0.85 & 0.81 \\
\hline $\begin{array}{l}\text { (Rafi ve diğerleri, } \\
\text { 2020) }\end{array}$ & Temel U-net & BRATS 2019 & 0.84 & 0.80 & 0.63 \\
\hline $\begin{array}{l}\text { (Aboelenein ve } \\
\text { diğerleri, 2020) }\end{array}$ & Hibrit iki kanallı U-net (HTTU-Net) & BRATS 2018 & 0.865 & 0.808 & 0.745 \\
\hline $\begin{array}{l}\text { (Zhang ve diğerleri, } \\
\text { 2020) }\end{array}$ & Dikkat ve Artık bloğu olan 2 boyutlu U-net (AResU-net) & BRATS 2018 & 0.876 & 0.810 & 0.773 \\
\hline $\begin{array}{l}\text { (Yang ve diğerleri, } \\
\text { 2020) }\end{array}$ & $\begin{array}{l}\text { Genişletilmiş evrişimli yapıya sahip yeni bir U-net } \\
\text { (DCU-Net) }\end{array}$ & BRATS 2018 & 0.91 & 0.78 & 0.83 \\
\hline $\begin{array}{l}\text { (Colman ve diğerleri, } \\
\text { 2020) }\end{array}$ & $\begin{array}{l}104 \text { evrişimli katmana sahip bir } 2 \text { boyutlu Derin Artık } \\
\text { bloklu U-net (DR-Unet104) }\end{array}$ & BRATS 2020 & 0.8862 & 0.6721 & 0.6756 \\
\hline $\begin{array}{l}\text { (Qamar, Ahmad ve } \\
\text { Shen, 2020) }\end{array}$ & Aşırı Yoğun Başlangıç Modüllü 3 boyutlu U-net (HINet) & BRATS 2020 & 0.874 & 0.837 & 0.794 \\
\hline $\begin{array}{l}\text { (Tan ve diğerleri, } \\
\text { 2021) }\end{array}$ & $\begin{array}{c}\text { Derin ayrılabilir konvolüsyon katmanlı, Artık atlama } \\
\text { bağlantıl1, Aktif kontur model eklemeli U-net (ACU-net) }\end{array}$ & $\begin{array}{l}\text { BRATS } 2015 \\
\text { BRATS } 2018 \\
\text { BRATS } 2019\end{array}$ & 0.9273 & 0.9580 & 0.8429 \\
\hline $\begin{array}{l}\text { (Awasthi, Pardasani ve } \\
\text { Gupta, 2021) }\end{array}$ & Çok-eşikli Dikkat bloklu U-net (MTAU) & BRATS 2020 & 0.72 & 0.61 & 0.59 \\
\hline $\begin{array}{l}\text { (Lin ve diğerleri, } \\
\text { 2021) }\end{array}$ & Derin denetimli yeni bir 3 boyutlu bağlam U-net & BRATS 2019 & 0.8693 & 0.8013 & 0.7782 \\
\hline \multirow{4}{*}{$\begin{array}{l}\text { (Ahmad ve diğerleri, } \\
\text { 2021) }\end{array}$} & \multirow{4}{*}{$\begin{array}{l}\text { Artık-Genişlemiş Yoğun Atlamal1-Uzaysal Piramit } \\
\text { Havuzlama (RD2A) } 3 \text { boyutlu U-net }\end{array}$} & \multirow{4}{*}{$\begin{array}{l}\text { BRATS } 2018 \\
\text { BRATS } 2019\end{array}$} & \multicolumn{3}{|c|}{ BRATS 2018} \\
\hline & & & 0.90 & 0.84 & 0.78 \\
\hline & & & \multicolumn{3}{|c|}{ BRATS 2019} \\
\hline & & & 0.90 & 0.82 & 0.71 \\
\hline
\end{tabular}

(W. Chen ve diğerleri, 2018) çalışmalarında, 2 boyutlu konvolüsyonların hacimsel medikal görüntü verilerinin uzamsal bilgisini tam olarak kullanamazken, 3 boyutlu konvolüsyonların yüksek maliyetli hesaplama maliyeti ve bellek talebinden muzdarip olduğu sorunlarını çözmek için, ayrılabilir 3 boyutlu evrişimler kullanan yeni bir Ayrılabilir 3 boyutlu U-net mimarisi önermiş̧lerdir. (S. Chen ve diğerleri, 2019) çalışmalarında, öğrenilen hiyerarşik özelliklerin kalitesini artırmak için bir dizi yaklaşım önermişlerdir. Katkıları dört yönden oluşmaktadır. İlk olarak, daha doğru segmentasyon için çok seviyeli bilgileri kullanmak üzere popüler DeepMedic modelini Çok Seviyeli DeepMedic'e genişletmişlerdir. İkinci olarak, derin modellerden öğrenilen çok seviyeli özelliklerin kalitesini teşvik etmek için yeni bir çift kuvvetli eğitim planı önermişlerdir. Genel bir eğitim 
şemasıdır ve birçok mevcut mimariye, örneğin DeepMedic ve Unet'e uygulanabilir. Üçüncü olarak, derin modellerin üst düzey katmanlarını daha soyut bilgiler öğrenmeye teşvik etmek için yardımcı sınıflandırıcı olarak etiket dağıtımına dayalı bir kayıp fonksiyonu tasarlamışlardır. Son olarak, derin modellerin tahmin sonuçlarını iyileştirmek için yeni bir Çok Katmanlı Algılayıcı tabanlı işlem sonrası yaklaşımı önermişlerdir. (H. Liu ve diğerleri, 2019) çalışmalarında, beyin tümörü segmentasyonu için yeni bir kademeli U-net önermişlerdir. Beyin tümörünün farklı hiyerarşik yapısından esinlenerek, önce tüm tümörün segmentlere ayrıldığı ve ardından tümörün iç alt yapılarının daha da segmentlere ayrıldığı kademeli bir derin ă̆ çerçevesi tasarlamışlardır. Kademeli yapıların getirdiği a ̆ derinliğinin artmasının daha derin katmanlarda doğru yerelleştirme bilgilerinin kaybolmasına yol açtığını düşünerek, özellikleri aynı çözünürlükte birbirine bağlamak ve ayrıntılı bilgileri sı̆̆ katmanlardan daha derin katmanlara iletmek için ağlar arası bağlantılar kurmuşlardır. Ardından, dengesiz veri sorununu ortadan kaldırmak için bir kayıp ağırlıklı örnekleme (LWS) şeması sunmuşlardır. (Wang ve diğerleri, 2019) çalışmalarında, beyin bazlı normalizasyon ve yama stratejileri yardımıla 3 boyutlu U-net tabanlı bir derin öğrenme modeli eğitmişlerdir. Ayrıca, tümör boyutunun beyin boyutuna oranı ve tümör yüzey alanı gibi sayısal özellikler ve deneklerin yaşı, tahmin edilen tümör etiketlerinden çıkartılmışlardır ve genel hayatta kalma günlerini tahmin görevi için kullanmışlardır. (Henry ve diğerleri, 2020) çalışmalarında, esas olarak derin denetim ve stokastik ağırlık ortalamasına sahip birden çok U-net gibi sinir ağlarını eğitmişlerdir. İki farklı eğitim hattından iki bağımsız model grubu eğitilmiştir ve ve her biri bir beyin tümörü segmentasyon haritası üretmişlerdir. Hasta başına bu iki etiket haritası daha sonra, her bir grubun spesifik tümör alt bölgeleri segmentasyonu için performansı dikkate alınarak birleştirilmiştir. Genel olarak yaklaşımları, her tümör alt bölgesi için iyi ve dengeli performans sağlamıştır.

(Rafi ve diğerleri, 2020) çalışmalarında, her pikseli segmentlere ayırmak için, dilim tabanlı 2 boyutlu U-net'in basitleştirilmiş bir versiyonunu tasarlamışlardır ve yaşam süresini tahmin etmek için radyomik özellikleri analiz etmişlerdir. (Aboelenein ve diğerleri, 2020) çalışmalarında, beyin tümörü segmentasyonu için bir Hibrit İki Kanallı U-net (HTTU-Net) mimarisi önermişlerdir. Bu mimari, Leaky Relu aktivasyonunu ve toplu normalizasyonu kullanmaktadır. Sonuçları oldukça karşılaştırılabilir uzman insan seviyesi performansı olduğunu doğrulamış ve uzmanların teşhis süresini azaltmalarına yardımcı olabilmiştir. (Zhang ve diğerleri, 2020) çalışmalarında özellik çıkarımında, dikkat mekanizmasını yerel önemli tepkilerin etkilerini keşfetmek için mevcut U-net mimarisine dahil etmişlerdir. Daha spesifik olarak, beyin tümörünün daha fazla performans iyileştirmesi için aynı anda dikkat mekanizmasını ve kalan birimleri U-net'e yerleştiren uçtan uca 2 boyutlu beyin tümörü segmentasyon ağ rezidüel U-net (AResU-Net) önermişlerdir. Beyin tümörü segmentasyon yöntemleriyle karşılaştırıldığında kenar çizgilerinin daha iyi bulduklarını görmüşlerdir. (Yang ve diğerleri, 2020) çalışmalarında, klasik U-net yapısına dayalı olarak beyin tümörü segmentasyonu için genişletilmiş evrişimli (DCU-Net) yapıya sahip yeni bir U-net önermişlerdir. MR beyin tümörü görüntüleri, arka plan piksellerinin girişini azaltarak sınıf dengesizliği sorununu hafifletmek için önceden işlenmiş sonrasında, çok ölçekli uzamsal piramit havuzlaması, aşağı örnekleme yolunun sonundaki maksimum havuzlamanın yerini almak için kullanılmıştır. Görüntü çözünürlüğü korurken özellik alıcı alanını genişletebilirdir. Son olarak, ağın tümör ayrıntılarını tanıma yeteneğini geliştirmek için eğitim ağlarındaki atlama bağlantılarını iyileştirmek için genişletilmiş bir evrişim kalıntı bloğu birleştirmişlerdir. (Colman ve diğerleri, 2020) çalışmalarında, beyin MR'larınde lezyon segmentasyonu için 104 evrişimli katmana (DR-Unet104) sahip bir 2 boyutlu derin Artık U-net önermişlerdir. Yalnızca 2 boyutlu konvolüsyonlar kullanmalarına rağmen rekabetçi bir lezyon segmentasyon mimarisi üretmişlerdir ve bunun 3 boyutlu mimariden daha düşük güçlü bilgisayarlarda kullanılabilmesi gibi ek bir fayda sağlamışlardır.

(Qamar ve diğerleri, 2020) çalışmalarında, kalıntı başlangıç bloğundaki 3 boyutlu ağırlıklı evrişimli katmanların çarpanlara ayrılmasını istifleyerek çok ölçekli bilgileri yakalayan hiper yoğun başlangıç 3 boyutlu U-net (HINet) önererek beyin tümörü segmentasyonunun performansını daha da artırmışlardır. Özelliklerin yeniden kullanılabilirliği yardımıyla daha fazla bağlamsal bilgi elde etmek için çarpanlara ayrılmış evrişimli katmanlar arasında aşırı yoğun bağlantılar kullanmışlardır. (Tan ve diğerleri, 2021) çalışmalarında, haritalanmış evrişimli kanalın uzamsal korelasyonunu ve görünüm korelasyonunu ayırt etmek için U-net'teki sıradan mimarinin yerini alacak derin ayrılabilir evrişimli katmanlar kullanmışlardır. Derin anormal bölgelerin yakalanmasını gerçekleştirmek için, özelliklerin yayılma kapasitesini artırmak ve ağın yakınsama hızını hızlandırmak için ACU-Net'e artık atlama bağlantısı eklemişlerdir. Aktif kontur modelini, görüntü gürültüsüne ve kenar kırılımlarına karşı kullanmak, tümör deformasyonunun takibini gerçekleştirmek ve ödem alanındaki kenar bulanıklığı sorununu çözmek, böylece tümör çekirdeğini ve gelişmiş nekrotik parankimal alanı tam olarak anormal alanda bölmek için kullanmışlardır. BRATS 2015 ve 2018 yıllarındaki 286 hastanın MR tarama verileri eğitim seti ve BraTS2019 veri seti de doğrulama için kullanmışlardır. (Awasthi ve diğerleri, 2021) çalışmalarında, U-net'e dayalı çok eşikli bir model geliştirmişlerdir. Önerilen model, paralel olarak eğitilirse daha az hesaplama karmaşıklığı, daha az bellek gereksinimi ve daha az eğitim süresi gibi avantajlar sunacaktır. (Lin ve diğerleri, 2021) çalışmalarında hem tüm beyin tümörünü hem de tümörlerin alt bölgelerini segmentlere ayırmak için derin denetimli yeni bir bağlam U-net geliştirmişlerdir. Bağlam modülü, beyin tümörleri hakkında daha fazla bilgi elde etmek için başlangıç benzeri bir yapıyla oluşturulmuştur. Kodlayıcı yolundaki derin denetim, ağın farklı seviyelerinde segmentasyon çıktılarının eklenmesiyle sağlanmıştır. (Ahmad ve diğerleri, 2021) çalışmalarında, Artık-Genişlemiş Yoğun Atlamalı-Uzaysal Piramit Havuzlama (RD2A) 3 boyutlu U-net önermişlerdir. Çok ölçekli bağlamsal bilgi, bebeğin beyin MR'ındaki beyaz madde ve gri madde dokuları arasındaki belirsizlikleri en aza indirmiştir. Önerilen yaklaşım beyin omurilik sıvısı, gri madde ve beyaz madde için sırasıyla $0.798,0.779$ ve 0.805 ortalama Dice skoruna ulaşmıştır.

\section{Sonuç}

Karmaşık beyin anatomisi, görüntü çözünürlüğü, standart yapıda olmayan MR görüntüleri gibi faktörler beyin görüntü analizini zorlaştırmaktadır. Ayrıca tıbbi veri miktarındaki kıtlık çok fazla veriyle beslenmesi gereken derin ağlar için sorun oluşturmaktadır. Literatürdeki son gelişmelere bakıldığında beyin analizi çalışmalarında derin öğrenme potansiyelinin arttığ görülmektedir. Derin öğrenme yöntemlerinden olan U-net daha az veriyle klasik makine öğrenme yöntemlerinden daha iyi performans göstermektedir. Basit ve genişletilebilir bir yapıda 
olup yüksek kalitede bölütleme sonuçları sunmaktadır. Bu çalışmada, U-net yöntemine dayalı glioma tümörü segmentasyonu literatür taraması sunulmuştur. Her bir tümör segmentasyon sonucunun performansı, etiketlenmiş ve tahmin edilmiş bölge arasındaki çakışmayı gösteren Dice skoru ile belirtilmiştir. U-net varyasyonları ile yapılan bu segmentasyon hekimlere tanı, ameliyat ve tedavi öncesinde yardımcı olup onların işlerini kolaylaştırmabilmesi bakımından önemlidir. Çeşitli görüntü işleme tekniklerini birleştirerek, derin öğrenme modellerini değiştirerek, hibrit mimariler kullanarak, ön işleme yaparak, parametre optimizasyonları ve veri kümesi boyutunu artırarak sonraki çalışmalarda daha yüksek Dice skorları elde edilebilir.

\section{Kaynakça}

Aboelenein, N. M., Songhao, P., Koubaa, A., Noor, A. ve Afifi, A. (2020). HTTU-Net: Hybrid Two Track U-Net for automatic brain tumor segmentation. IEEE Access, 8, 101406-101415.

Ahmad, P., Jin, H., Qamar, S., Zheng, R. ve Saeed, A. (2021). RD 2 A: densely connected residual networks using ASPP for brain tumor segmentation. Multimedia Tools and Applications, 1-26.

Awasthi, N., Pardasani, R. ve Gupta, S. (2021). Multi-Threshold Attention U-Net (MTAU) based Model for Multimodal Brain Tumor Segmentation in MRI scans. arXiv preprint arXiv:2101.12404.

Bakas, S., Akbari, H., Sotiras, A., Bilello, M., Rozycki, M., Kirby, J. S., ... Davatzikos, C. (2017). Advancing the cancer genome atlas glioma MRI collections with expert segmentation labels and radiomic features. Scientific data, 4(1), 1-13.

Bakas, S., Reyes, M., Jakab, A., Bauer, S., Rempfler, M., Crimi, A., ... others. (2018). Identifying the best machine learning algorithms for brain tumor segmentation, progression assessment, and overall survival prediction in the BRATS challenge. arXiv preprint arXiv:1811.02629.

Chen, S., Ding, C. ve Liu, M. (2019). Dual-force Convolutional Neural Networks for Accurate Brain Tumor Segmentation. Pattern Recognition, 88, 90-100.

Chen, W., Liu, B., Peng, S., Sun, J. ve Qiao, X. (2018). S3DUNet: Separable 3D U-Net for Brain Tumor Segmentation. International MICCAI Brainlesion Workshop içinde (ss. 358-368).

Chihati, S. ve Gaceb, D. (2020). A Review of Recent Progress in Deep Learning-based Methods for MRI Brain Tumor Segmentation. 2020 11th International Conference on Information and Communication Systems, ICICS 2020 içinde (ss. 149-154). Institute of Electrical and Electronics Engineers Inc.

Colman, J., Zhang, L., Duan, W. ve Ye, X. (2020). DR-Unet104 for Multimodal MRI brain tumor segmentation. arXiv preprint arXiv:2011.02840.

Ghaffari, M., Sowmya, A. ve Oliver, R. (2019). Automated brain tumor segmentation using multimodal brain scans: a survey based on models submitted to the BraTS 2012--2018 challenges. IEEE reviews in biomedical engineering, 13, 156-168.

Havaei, M., Davy, A., Warde-Farley, D., Biard, A., Courville, A., Bengio, Y., ... Larochelle, H. (2017). Brain tumor segmentation with deep neural networks. Medical image analysis, 35, 18-31.
Henry, T., Carre, A., Lerousseau, M., Estienne, T., Robert, C., Paragios, N. ve Deutsch, E. (2020). Brain tumor segmentation with self-ensembled, deeply-supervised 3D Unet neural networks: a BraTS 2020 challenge solution.

Hu, Y. ve Xia, Y. (2017). 3D Deep Neural Network-based Brain Tumor Segmentation Using Multimodality Magnetic Resonance Sequences. International MICCAI Brainlesion Workshop, 423-434.

Isensee, F., Kickingereder, P., Wick, W., Bendszus, M. ve MaierHein, K. H. (2018). No new-net. International MICCAI Brainlesion Workshop içinde (ss. 234-244).

Kim, G. (2017). Brain Tumor Segmentation Using Deep Fully Convolutional Neural Networks. International MICCAI Brainlesion Workshop içinde (ss. 344-357). Springer, Cham.

Kong, X., Sun, G., Wu, Q., Liu, J. ve Lin, F. (2018). Hybrid Pyramid U-net Model for Brain Tumor Segmentation. International conference on intelligent information processing içinde (ss. 346-355).

Lin, M., Momin, S., Zhou, B., Tang, K., Lei, Y., Curran, W. J., ... Yang, X. (2021). Fully automated segmentation of brain tumor from multiparametric MRI using 3D context u-net with deep supervision. Medical Imaging 2021: ComputerAided Diagnosis içinde (C. 11597, s. 115971I).

Liu, H., Shen, X., Shang, F., Ge, F. ve Wang, F. (2019). CU-Net: Cascaded U-Net with Loss Weighted Sampling for Brain Tumor Segmentation. Multimodal Brain Image Analysis and Mathematical Foundations of Computational Anatomy içinde (ss. 102-111). Springer, Cham.

Liu, L., Cheng, J., Quan, Q., Wu, F.-X., Wang, Y.-P. ve Wang, J. (2020). A survey on U-shaped networks in medical image segmentations. Neurocomputing, 409, 244-258.

Louis, D. N., Perry, A., Reifenberger, G., Von Deimling, A., Figarella-Branger, D., Cavenee, W. K., ... Ellison, D. W. (2016). The 2016 World Health Organization classification of tumors of the central nervous system: a summary. Acta neuropathologica, 131(6), 803-820.

Mathews, C. ve Mohamed, A. (2020). Review of Automatic Segmentation of MRI Based Brain Tumour using U-Net Architecture. 2020 Fourth International Conference on Inventive Systems and Control (ICISC) içinde (ss. 46-50).

Menze, B. H., Jakab, A., Bauer, S., Kalpathy-Cramer, J., Farahani, K., Kirby, J., ... others. (2014). The Multimodal Brain Tumor Image Segmentation Benchmark (BRATS). IEEE transactions on medical imaging, 34(10), 1993-2024.

Nadeem, M. W., Ghamdi, M. A. Al, Hussain, M., Khan, M. A., Khan, K. M., Almotiri, S. H. ve Butt, S. A. (2020). Brain tumor analysis empowered with deep learning: A review, taxonomy, and future challenges. Brain sciences, 10(2), 118.

Qamar, S., Ahmad, P. ve Shen, L. (2020). HI-Net: Hyperdense Inception 3D UNet for Brain Tumor Segmentation. arXiv preprint arXiv:2012.06760.

Rafi, A., Ali, J., Akram, T., Fiaz, K., Shahid, A. R., Raza, B. ve Madni, T. M. (2020). U-Net Based Glioblastoma Segmentation with Patient's Overall Survival Prediction. International Symposium on Intelligent Computing Systems içinde (ss. 22-32).

Rajput, S. ve Raval, M. S. (2020). A Review on End-To-End Methods for Brain Tumor Segmentation and Overall Survival Prediction. arXiv preprint arXiv:2006.01632.

Ronneberger, O., Fischer, P. ve Brox, T. (2015). U-net: Convolutional networks for biomedical image segmentation. International Conference on Medical image computing and computer-assisted intervention içinde (ss. 234-241). 
Shreyas, V. ve Pankajakshan, V. (2017). A Deep Learning Architecture for Brain Tumor Segmentation in MRI Images. 2017 IEEE 19th International Workshop on Multimedia Signal Processing(MMSP) içinde (ss. 1-6). Institute of Electrical and Electronics Engineers Inc.

Siddique, N., Sidike, P., Elkin, C. ve Devabhaktuni, V. (2020). U-Net and its variants for medical image segmentation: theory and applications. arXiv preprint arXiv:2011.01118.

Tan, L., Ma, W., Xia, J. ve Sarker, S. (2021). Multimodal Magnetic Resonance Image Brain Tumor Segmentation Based on ACU-Net Network. IEEE Access, 9, 1460814618.

Tüzün, E., Hanağası, F., Sabancı, P. A., Demir, G. A. ve Yazıcı, J. (y.y.). NÖRO-ONKOLOJI. 23 Mayıs 2021 tarihinde http://www.itfnoroloji.org/onkoloji/onkoloji.htm adresinden erişildi.

Wang, F., Jiang, R., Zheng, L., Meng, C. ve Biswal, B. (2019). $3 \mathrm{~d}$ u-net based brain tumor segmentation and survival days prediction. International MICCAI Brainlesion Workshop içinde (ss. 131-141).

Yang, T., Zhou, Y., Li, L. ve Zhu, C. (2020). DCU-Net: Multiscale U-Net for brain tumor segmentation. Journal of X-Ray Science and Technology, (Preprint), 1-18.

Zhang, J., Lv, X., Zhang, H. ve Liu, B. (2020). AResU-Net: Attention Residual U-Net for Brain Tumor Segmentation. Symmetry, 12(5), 721. 